\title{
The Role Positioning of Ideological and Political Education Workers in the Process of College Marxism Popularization
}

\author{
Mingmin $\mathrm{Li}^{1, \mathrm{a}^{*}}$ and Jing $\mathrm{Li}^{1}$ \\ ${ }^{1}$ School of Marxism, Xi 'an jiaotong University, Xi'an 710049,PR China \\ ${ }^{2}$ School of Marxism, Weinan Normal University, Weinan 714099, PR China
} Keywords: Ideological and Political Education; College; Marxism; Popularization; Development
Process

\begin{abstract}
Today, ideological and political education work is showing a new trend of globalization and popularization in the process of college Marxism popularization. In the new era under new development perspective, the key content of modern China's ideological and political education development should be studied is: Whether ideological and political education can guarantee the purpose of common survival of all mankind; Whether ideological and political education can meet the needs of the ideological and political education workers' development in China; Whether ideological and political education can promote the common progress of all mankind. In order to retain the original theoretical characteristics, the new period Marxist teaching reflects very obviously value tendentiousness. To achieve this, it is important to combine the trend of democratization and internationalization of ideological and political education with the development path of traditional ideological and political education. It is the key point of the paper as well as the development connotation of ideological and political education work which our government has attached great importance to.
\end{abstract}

\section{Introduction}

In the case of cultural globalization and localization becoming increasingly apparent, the human society is facing with a very important problem in the development of political thought area. Especially in the development process of Marxist education, localization and popularization, it is necessary to combine modern Marxist education and the essence of political development with the development of the people's ideology and life. And then, a modern political development education model and higher form of ideological and political education development pursuit would be demonstrated. Closely connect the progress of Marxism in China and the new situation of China development. Make Marxism show the unique charm of socialist ideological politics and the future development trend of modern ideological and political development will be shown. Let the spiritual products of all ethnic groups become the property of the nation. Promote the comprehensive development of nation and break the limitations of ideological and political education. And combine the thinking model of Marxist development with the needs of localization and popularization.

\section{The role of ideological and political education work in Marx-Leninism construction}

The development strategy of Marxism popularization. The development of Marxism popularization is a new attempt of promoting scientific development concept, socialism development view and Marxism-Leninism education of a mass character. It is the inevitable requirement of Marxist propulsion process as well as the internal demands on keeping youth and getting permanent vitality of Marxist theory. This is because the rapid development of economy challenges people's ideological and realm development in our country. Therefore, enhancing the combat power of nationalism in the new era resulted in the realistic demand for cultivating new socialist. Marxist popularization development strategy asks the ability of exploring approaches for carrying out ideological and political education in colleges. 
The dominant role of Marxism popularization. The report of the 17th Party Congress showed that carry out socialism theory system with Chinese characteristics and popularization work are the key strategy of the development of Marxist popularization in contemporary China. Marxism and the public are inseparable. In the past historical political struggle, Marxism went into people's lives and be understood and applied by more people. Today, colleges have become the main position in spreading of Marxist theory. In peacetime, the spread and education of Marxism reflect an actual effect of excessive stereotypes in the process of ideological and political guidance and political education. Therefore, at this stage, to promote the popularization of Marxism in colleges, Marxist educators need to grasp the leading role of Marxist education and do not make it out of reality and student life. Just simply empty teaching on theory couldn't meet the modern teaching requirements. Marxist teaching couldn't blindly cater to students. Marxist philosophy principle couldn't be distorted for wanting to guide the initiative and enthusiasm of students. It should be under the situation of closing to reality to make Marxist teaching popularization. Make Marxist theory show the actual guiding line to explain the difficult problems in real life. Solve practical problems and at the same time to digest the students' psychological inversion on learning Marxist theory.

\section{Leader Role and Leading Task}

Colleges are the main position for spreading Marxist theory. Colleges are the main position for spreading Marxist theory. This is because colleges can mobilize the enthusiasm of students. It can stimulate students' desire for knowledge from the point of indoctrination in wide range. So that Marxist theory can really go into students' heart. The mainstay of Marxist popularization is mainly concentrated in colleges. This is because the ideological and political teachers in colleges have a higher level and they can quickly grasp the change direction of Marxist theory education. Therefore ensure the education objectives in line with socialist values and core concepts. Especially in the process of guiding students' interest and education, it can better adopt the core values of new era socialism development and combine with traditional Marxist theory. Ideological and political teachers in colleges can mobilize the enthusiasm of students through careful arrangements on ideological and political education. They can fully guarantee the process to meet their education and make the education carry out health and orderly. Then, we can ensure that all the profound theoretical system can gradually connect with students' comprehensive ideas and accept situation. In the aspect of ideological and political education teaching content and adaptation system, educators should choose a comprehensive knowledge system as much as possible. And it will have a good effect on reducing the cost of education. It is also the necessary conditions to obtain educational effect and the inevitable path for educators to improve the comprehensive quality in new era.

The popularization process of esoteric Marxist theory. In the process of Marxist ideological and political education, the most vexing question is Marxist theory is too mysterious in sometimes. Especially surplus value theory or the combination and conversion process of Marxism theoretical practice. In the process of theoretical study, teaching theory system actually is not immutable. However, many learners may only continually memorize Marxist theory on book which makes the study on Marxist theory lagging behind and couldn't effectively focus on people's livelihood. What's more, these studies are out of specific reality and are empty and unpersuasive. When doing education in colleges, in the process of talking about the combination of Marxist education and practical enterprise practicality, many educators established joint bases of colleges and enterprises. As a result, the integration of socialist diversification and political thought theory has made new development at this stage. Therefore, in the work of Marxist education in colleges, we can combine with the popular theory education background in new era. Through adding new content of education and improving new requirements to in-depth study the regularity of Marxist theory ideological education system. Therefore, popularize Marxist pure theory to popular education. Lead its popularization in the whole society through popularizing Marxism in students. According to the theoretical level of Marxist ideological and political educators to adapt to new situation in new period of development and promote the development of Marxist popularization in the popular society. 
Mobilize the enthusiasm of Marxist autonomic learning. In the popularization process of Marxist education, as Marxist education process is a complex and arduous system engineering, achieving Marxism popularization in colleges education needs the strength integration from various parts and organization sectors of colleges. It is the guarantee of the success of Marxism popularization to enhance students' enthusiasm of Marxist autonomic learning. To better play the guiding role of Marxist theory and combine the application results of Marxism with practical problems, require ideological and political educators be good at combining theory with practice. Continue to achieve innovation and complete the new development goals and requirements. The learning enthusiasm of students is based on the success of Marxist popularization. Therefore, use a variety of teaching methods (such as multimedia teaching and micro-class teaching methods) to narrow the distance between Marxist educational theory and real life. So that students can study and grasp the learning regulation of Marxism through a variety of teaching methods. Understand the learning differences between Chinese and Western Marxist, do organic connections between the various differences and then we can use Marxist practical principles to explain various problems in production and lifetime. Study learning regulation can naturally make use of the demonstration and role model function to enhance the enthusiasm of Marxist learning.

\section{The role and research focus of Marxist researchers in colleges}

Keep pace with the times to study and research on Marxist theory. When learning Marxism we can't be all talk and no deed. The learning demonstration effect of Marxist is very important. Keep pace with the times to study and research on Marxist theory, enhance the credibility and persuasiveness of Marxist theory in students and then we can be able to enhance the authority of it. To enhance the prestige of Marxism in new era, we must constantly meet the requirements of Marxist educational innovation and add some specific details of Marxism popularization process. To achieve the popularization of Marxist education, do first and then sum up. Make the ideological and political workers rushed in the forefront of Marxist learning and popularization. In the process of Marxist education construction, although we can't determine the popularization course by students' interests, after all, students are the main learning audiences of Marxism popularization. Therefore, in the course of Marxism popularization evolution, it is necessary to supplement content that students are interested in with the times and not ignore their learning interest. And then we can be able to create the basis of good learning effect for Marxist theory.

Adjust the role of Marxist coordinator and role orientation. Marxist educators are the role of coordinating ideological and political education. They play the role of role-oriented. In order to enhance the generally acceptance of students on community on Marxism, the specific situation of students need to be accepted and be treated differently. Coordinate the actual education of Marxism to local conditions and right time. This requires the Marxist college education teachers come with the role of coordinator and fugleman. Students are the subject of learning, teachers play a leading role. Under the background of general education and satisfying popularity, do not ignore the actual needs of student community. Take into account the role of coordinator in terms of curriculum and timing arrangements and the progress of curriculum. Make use of the rich theoretical achievements and foundations from Marxism, combine the satisfying of basic principles and actual situation in China with Mao Zedong Thought and Deng Xiaoping Theory. Coordinate the problems may arise in learning process. The orientation function of coordinator is very important. Because of this coordinator and fugleman role, the requirements to ideological and political educators in colleges have become higher. In the process of constantly studying the popularization of Marxism and its exemplary role, it is necessary to establish a good relationship between teachers and students. Make it easier for students to accept the role of demonstrators and coordinators and willing to put Marxist practical work into action.

Ideological and political educators are good at combining theory with practice. Ideological and political educators must be good at combining Marxism theory with practice. It is because practice is the basis of theory as well as the source of theory. Theory can guide practical work, it is the essence extracted from practical work. General Secretary Xi Jinping has pointed out in national 
ideological and political work conference: In order to do ideological and political education well in colleges, we should make analysis according to the actual situation. Make corresponding progress according to different background and achieve continuous innovation in accordance with the facts and forms. In order to meet the actual rule of teaching and the law of natural growth, ideological and political work in colleges must have clear thinking and direction. To grasp the theory and working rule of ideological and political work, we must combine with the impact of social environment. Constantly think about social life practice and human self-cultivation. Through circularly understanding the specific process of ideological and political work; through strengthening the recognition of the law between subject and object and the law of ideological transformation, to carry out unity of knowledge and practice teaching. Adhere to coordinate the principle of material benefit origin with comprehensive means. Combine with the dual education approach of theoretical and practical encouragement, spiritual incentives and material incentives to play important role in ideological and political education work. Teaching and education are inseparable. In combining ideological and political courses with college professional courses, Marxist theoretical knowledge can not only arm the brain of students, but also can inspire the concept of college students and become their life guidance. Become students' inspiration source and driving force. In the process of strengthening its connection with other professional courses, explore the progress of Marxist values and view of live development. Combine life philosophy with future goal. Make Marxist theory develop from fuzzy to clear. Enhance the social responsibility concept of college students and drive the continuous development and strengthening of the whole social concept.

Ideological and political educators guide the public to carry out Marxist innovation. The so-called popularization of Marxism is hoping to be able to combine the current overall psychological and personality development of college students to achieve the transform from the caring about books to social. The theory of Marxist contradiction development puts forward new requirements to college students on aging and the accumulation of knowledge and experience. Marxism popularization should not only adapt to the psychological situation of college students, but also improve college students' level of Marxism when improving the whole society's socialism core concept construction level. In other words, the principle of deepening the rapid development of ideological and political education is: Broaden the horizons of college students; provide a broad knowledge base and curriculum accumulation; strengthen citizens' ideology education and make civic awareness and the economic base in modern society coordinated development; form the right-obligation notion of fair and equitable rights; make students learn to live with others in harmony and equality. Earnestly respect the concept of legitimate rights of others and reinforce ideological and political education. Understand the socialist ideology and consciously implement Marxist ideology and the party's line policy. Continuously improve their political level and ideology through practice. Through rigorously explore and pursue ideological and political education of college students, to enhance the future ideological and political realm of the public.

\section{Conclusion}

The process of cultivating the popularization of college ideological and political education is the process of improving ideological and political quality of college students. Enhance the timeliness of ideological and political theory. Social practice teaching and ideological and political teaching also can't be ignored. In the process of cultivating college students, establish a complete transmission system and knowledge system through continuous pioneering spirit. Effectively combine social practice teaching with ideological and political teaching - the two essential ideological and political education links. Provide strong teaching weapons for long-term ideological and political theory educators. Cultivate the viability of college students in the process of Marxist learning, and enhance their ability on using knowledge and making innovation. The process of cultivating the popularization of college ideological and political education is the process of improving ideological and moral quality, scientific and cultural quality of college students and accelerating the 
development of physical and mental quality. Combine theory with practice to learn Marxism advancing with the times. Focus on politics and develop future reflect

\section{Acknowledgements}

This work was financially supported by Shaanxi Social science 2017 key projects of major theoretical and practical problems research(2017ZH007), "The 13th five-year development planning" major scientific projects of Weinan Normal University(Research on the popularization of marxism and college students' education management).

\section{References}

[1] P.J. Z: Educational Research, (2015), No. 04, p.42-48.

[2] Y. H: Journal of Sichuan University of Science and Technology (Social Science Edition), (2015), No. 01, p.34-46, Information http://kns.cnki.net/kcms/detail/51.1676.C.20150309.0854.007.html

[3] X.J. W, K. L: Research on Ideological Education, (2015), No.02, p.18-22.

[4] Y.C. Z, G.R. Q: Research on Ideological Education, (2014), No.07, p.3-9.

[5] Y.T. Z: Research on Ideological Education, (2014), No.04, p.3-18.

[6] D.Q. J: Promoting the Popularization of Marxism in Colleges with the Basis of Ideological and Political Theory (Anhui University, 2013).

[7] N. L: Study of Citizens' Consciousness Education from the Perspective of Ideological and Political Education (China University of Geosciences, 2012).

[8] W.X. Z: Study on the Institutionalization of College Students' Ideological and Political Education (China University of Geosciences, 2012).

[9] Y.T. L: Marxist research, (2012), No.09, p.120-137.

[10]X.H. S, J. L: Research on Audio - visual Education, (2012), No.09, p.27-30, Information on 10.13811/j.cnki.eer.2012.09.019

[11]L. T: Study on the Construction of Marxist Popular Carrier in Colleges (Guangxi University, 2012).

[12]Q.G: Reform and Opening Up, (2010), No.12, p.196-197, Information on 10.16653/j.cnki.32-1034/f.2010.12.002 